\title{
Applying environmental management policy for sustainable development of coastal tourism in Thailand
}

\author{
Phongphanich Nara', Guan-Guay Mao ${ }^{2,}$, , Tsair-Bor Yen ${ }^{1}$ \\ ${ }^{1}$ Department of Tropical Agriculture and International Cooperation, National Pingtung University of Science and Technology, Pingtung, \\ Taiwan \\ ${ }^{2}$ Graduate Institute of Landscape Architecture and Recreation Management, National Pingtung University of Science and Technology, \\ Pingtung, Taiwan
}

\section{Email address:}

rara_ha@hotmail.com (P. Nara), maogg@mail.npust.edu.tw (Guan-Guay Mao), tbyen@mail.npust.edu.tw (Tsair-Bor Yen)

\section{To cite this article:}

Phongphanich Nara, Guan-Guay Mao, Tsair-Bor Yen. Applying Environmental Management Policy for Sustainable Development of Coastal Tourism in Thailand. International Journal of Environmental Protection and Policy. Vol. 2, No. 1, 2014, pp. 19-23. doi: $10.11648 /$ j.ijepp.20140201.13

\begin{abstract}
Coastal tourism destination is one of the fastest growing areas within the world's largest tourism industry. In Thailand, large numbers of tourists come to coastal recreation areas, and the associated development is not well managed, there can be extremely negative effects on coastal environment. Also, the environmental impacts of coastal tourism are influenced by climate change impacts. The aim of article explores environmental management policy of coastal tourism to gather strategy and action for solving environmental impacts and applying sustainable development (SD) of coastal tourism. Hence, the findings of study show that key environmental impacts provide valuable lessons for coastal recreation areas. It also proposes the appropriate environmental management policy of coastal tourism in Thailand.
\end{abstract}

Keywords: Coastal Tourism, Environmental Impacts, Environmental Management Policy, Sustainable Development

\section{Introduction}

Tourism is currently one of the world's largest industries and fastest growing economic sectors. According to the World Tourism Organization (UNWTO), international arrivals worldwide have more than doubled since 1990 , rising from 435 million to 675 million in 2000, and to 940 million in 2010 [1, 2]. According to the Department of Tourism and the Tourism Authority of Thailand, international tourist is increased $15,936,400$ million tourists and 19,098,323 million tourists in 2010 and 2011 respectively. Growth rates have averaged around 19.84\% from 2010. This is expected an increase up to 20 million tourists in 2013 [3, 4, 5]. Table 1 shows the top ten countries ranking of annual growth in travel and tourism investment during 2011-2021. Thailand is received $8.8 \%$ or number 4 of countries ranking [1].

Coastal areas in particular have unique natural and man-made tourism facilities that make tourists attractive destinations for millions of visitors annually, has become one of the new frontiers and fastest growing areas of the world's tourism industry $[6,7]$. In Thailand, the concept of coastal tourism encloses the full range of tourism, leisure, and recreation activities that take place in the coastal zones. The characteristics of coastal ecosystem have always created contrasts especially along the Thailand coast where beaches are the main reasons for visiting the various destinations. Hence, coastal tourism is widely regarded as one of the fastest growing areas of contemporary tourism $[7]$.

Table 1. Top Ten Countries Ranking of Annual Growth in Travel and Tourism Investment, 2011-2021

\begin{tabular}{ccc}
\hline Ranking & Country & $\mathbf{\%}$ \\
\hline 1 & Montenegro & $16.4 \%$ \\
2 & Singapore & $9.3 \%$ \\
3 & Azerbaijan & $9.1 \%$ \\
4 & Thailand & $8.8 \%$ \\
5 & India & $8.7 \%$ \\
6 & Lithuania & $8.5 \%$ \\
7 & China & $8.5 \%$ \\
8 & Egypt & $7.8 \%$ \\
9 & Myanmar & $7.7 \%$ \\
10 & Fiji & $7.6 \%$ \\
\hline
\end{tabular}

Note: *\% annual growth in travel and tourism's contribution to total capital investment [1]. 
Therefore, the purpose of study is to explore an overview of environmental impacts, to gather environmental policy, and to propose guidelines for the SD of coastal tourism in Thailand.

\section{Literature Review}

The concept of SD has become a major issue all over the world by the report of the World Commission on Environment and Development in the $1987 \mathrm{~s}$ as "development that meets the needs of the present without compromising the ability of future generations to meet their own needs" [8]. The outcomes of SD at the Rio Declaration, Agenda 21 and the Johannesburg Plan of Implementation, attempt to promote these ideas [9].

In tourism, SD also has been recognized as a form of sustainable tourism which is expected to contribute to both conservation and development. The UNWTO proposed a definition of sustainable tourism development (STD) that meets the needs of present tourists and host communities whilst protecting and enhancing opportunities for the future. STD is seen as a tool to management of all resources in such a way that economic, social equity, and essential ecological processes for achieving sustainability [9, 10].

Additionally, STD also is available in the sustainable coastal tourism (SCT) by the United Nations Environment Programme (UNEP). The UNEP has proposed the strategic planning process for SCT to convert a constant level of physical resource use to the increased satisfaction of human needs, especially environmental management $[11,12]$.

In addition, coastal destination which provides the point of contact between land and sea and between cultures also contains historic communities, ports, and coastal defense, all of which may be attractions. However, in order to minimize tourism-induced problems and secure both the sustainability of the tourism industry and coastal resources used by other sectors, increased attention must be paid to the integration of coastal tourism into development planning [12].

Therefore, tourism development plan is the utmost importance to focus on an appropriate and realistic annual rate of tourism growth for sustainable coastal development and capacity of local community systems.

\section{Methodology}

This article is synthesized by the secondary data of Thai government reports and research papers based on the environmental policy, it is also analyzed the primary data by an in-depth interview with the 65 samples. A sample size has defined experts involved the study topic from public sector, non-governmental organization (NGO), and scholar by quota samplings technique.

Table 2 shows the information of sample that there are 40 government offices, 20 scholars, and 5 NGO officers in Thailand.
Table 2. The information of sample

\begin{tabular}{|c|c|}
\hline Respondent type & Sample size \\
\hline \multicolumn{2}{|l|}{ 1) Government offices } \\
\hline $\begin{array}{l}\text { - Department of Disaster Prevention and Mitigation } \\
\text { (DDPM) }\end{array}$ & 5 \\
\hline - $\quad$ Department of Local Administration (DLA) & 5 \\
\hline $\begin{array}{l}\text { - Office of Natural Resources and Environmental } \\
\text { Policy and Planning (ONEP) }\end{array}$ & 5 \\
\hline - $\quad$ Pollution Control Department (PCD) & 5 \\
\hline - $\quad$ Department of Fisheries (DOF) & 5 \\
\hline - $\quad$ Department of Land Transport (DLT) & 5 \\
\hline $\begin{array}{l}\text { - Department of Public Works and Town \& Country } \\
\text { Planning (DPT) }\end{array}$ & 5 \\
\hline - $\quad$ Department of Tourism (DOT) & 5 \\
\hline \multicolumn{2}{|l|}{ 2) NGO officers (and/or independent entity) } \\
\hline - $\quad$ Tourism Authority of Thailand (TAT) & 5 \\
\hline \multicolumn{2}{|l|}{ 3) Scholars } \\
\hline Faculty of Architecture, Chulalongkorn university & 20 \\
\hline
\end{tabular}

\section{Result and Discussions}

\subsection{Environmental Impacts of Coastal Tourism in Thailand}

The results of secondary data show that coastal destinations in Thailand have rapidly changed due to the combination of natural and anthropogenic forces, particular to the impacts of climate change and tourism development. These characteristics led over the years to the emergence of coastal environmental impacts of country.

Currently, climate change is the biggest and most controversial issue all over Thailand. It has an effect many aspects such as socio-economic, well-being of human and particular to environment [13, 14], which it has very importance of tourism sector that has moved to centre stage in the last few years [1]. Moreover, changes in climate are the most serious ones [12], affecting environment of coastal tourism in Thailand, the southwest monsoon (from mid-May to mid-October) and northeast monsoon (from mid-October to mid-February) also bring plenty amounts of storm and extreme weather conditions over the coastal destinations of the country $[15,16]$. Also, the International Disaster Database (EM-DAT) reports that the increase in serious occurrence of natural disaster events in Thailand during 1991-2011 [17]. Thus, the climate change impacts are caused the negative environmental impacts of coastal tourism in Thailand such as "natural disasters" and "coastal and marine ecosystems" [2, 11, 4, 5].

Furthermore, coastal recreation areas of Thailand have greatly deteriorated with human activities, in particular expansion of tourism, cited as one of the major causes [18]. Coastal tourism development can be the most important activity, generating economic benefits and therefore contributing to poverty alleviation. It also is an activity, bringing different cultures and customs together. 
Nevertheless, it is usually one of the most important factors of environmental impacts, and the net result is both short-term and long-term impacts on environmental resources of country. The short-term impacts are basically related with the construction phase of projects such as construction of accommodations or hotel buildings, development of infrastructure and public utilities. The long-term effects are normally associated with the operation and maintenance of tourism development components and tourist activities. These issues can impact either directly or indirectly on the coastal environments [12]. Clearly, the environmental impacts of coastal tourism in Thailand have many issues under increasing pressure from the tourism industry such as "pollution and environmental quality", "infrastructure and facilities", and "transportation and land use" [19, 11, 7, 4, 5].

In addition, the findings of primary data show that most of respondents' opinions refer the same 5 key issues of environmental impacts above. They mention that these key issues can be divided into 15 indicators of environmental impacts in table 3 . They also indicate that these key issues and indicators of environmental impacts are influenced by the natural and anthropogenic forces. Therefore, environmental impacts of coastal tourism in Thailand need to implement the environmental management policy for effectively SD.

\subsection{Environmental Management Policy of Coastal Tourism in Thailand}

Even though climate change and tourism development impacts could lead to negative effects of coastal environment, therefore careful managing and decision-making in tourism development is extremely important for preventing and mitigating negative influence to coastal recreation areas in Thailand $[2,11,5]$. Because of the significance of the coastal ecosystem and resources at many of the coastal tourism destinations, also may be damaged by poorly planned and/or managed tourist operations [19].

Presently, Thailand is now taking into account the conflict between developmental requirements and the need to coastal environmental management. Thailand could not be achieved the management plan of coastal destination rich with environmental and tourism resources, also it lack a guidelines for effective SD plan to regulate the exploitation of these resources [12, 20, 21]. Accordingly, the environmental effects identified above can provide incentives for effective management of the coastal recreation areas, which are tourist destinations thereby enhancing the qualities of the coastal ecosystem and resources that initially attracted tourists in Thailand $[19,11$, 2].

Therefore, this article has suggested a guideline of coastal environmental management for SD of country, including the key environmental management policy or action relate to importance of issues.

\subsubsection{Natural Disasters Management}

In Thailand, the policy framework for disaster risk reduction and disaster prevention and preparedness plan involves a wide range of institutions at the national, provincial, district and community levels. There are three disaster management policies including the formulation of the National Civil Defense Plan for 2005, Disaster Prevention and Mitigation Act for 2007, National Disaster Prevention and Mitigation Plan, and its evaluation and implementation, and the organization of annual or periodical trainings [22, 23].

At the provincial level, the provincial disaster prevention and mitigation office is the primary organization for disaster risk reduction under the Department of Disaster Prevention and Mitigation (DDPM) and provincial governor's office in the Department of Local Administration (DLA). There are plans aim to integrate infrastructure and communication systems development and capacity building for volunteer rescue and recovery operations.

At district level, the Tambon Administration Organizations (TAO) also play a coordination role in the disaster risk reduction process under the DDPM and DLA, where the main responsibility is allocated to the sub district level including village and community, as well as coastal areas of country [24, 23].

\subsubsection{Coastal and Marine Ecosystems Management}

The Tourism Development Plan (TDP) for 2012-2016 has been set for implementation of tourism. The second strategy of this plan involves the development and rehabilitation of coastal ecosystem and resources in tourism sites. It also mentions the improvement of various rules and regulations to enhance the country's potential for accommodating more tourist arrivals, by the TAO under the DLA.

According to the Environmental Quality Plan for 2012 2016 and the Economic and Social Development Plan for 2012 - 2016, there are contents of environmental quality development and promotion of cooperation from all sectors. In tourism, these plans determine the standards of tourism product and service to environmentally friendly or eco-friendly, and social responsibility and qualification of environmental personnel in tourism industry. Environmental quality development is the central goal of the plan, which was approved by the National Environmental Board meeting on 17 November 2011 [25, 26].

\subsubsection{Pollution and Environmental Quality Management}

According to the Pollution Control Department (PCD) is the main organization setting pollution management policies and measures that mentions the Pollution Management Plan for 2012-2016, it is developed for the next five years. The objective of this plan has been determined aiming at developing industrial and agricultural sectors, tourism, communication, transport, commerce and services at the same time to keep up with population 
increase, urbanization and global changes.

In relation with the coastal tourism, the objective is also assigned to make the environment suitable for development and maintain ecological balance by the Marine Department and Officers under the Department of Fisheries (DOF). It is also defined the pollution control measures and training to solve environmental impacts for SD. Also, it is referred criteria of reporting environmental impacts for projects or businesses that might cause severe impacts on communities and coastal areas [26].

\subsubsection{Infrastructure and Facilities Management}

In order to achieve aim of the TDP, the strategy attempts to develop infrastructure and facilities. This plan also specified the necessary role tourism industry for infrastructure and facilities development by each TAO. It has allocated budget for promotion tourism under the Department of Tourism (DOT) and Tourism Authority of Thailand (TAT) [25]. Moreover, infrastructure and facilities management on coastal tourism can follow the policies of the Pacific Area Travel Association (PATA). The PATA code provides useful guidelines for the tourism infrastructure and tourism facilities [11, 27]. This information can be useful for managing, planning and design actions (e.g. decisions about development controls, conservation measures, architectural and landscape elements design guidelines, etc.) that have the aim of making future STD of country [18].

\subsubsection{Transportation and Land-use Management}

According to the TDP, the first strategy also seeks to develop transportation, liking with domestic and international tourism of region under DOT and TAT. Also, the coastal areas can enforce the Town Planning Act 1975 and 1992 (No.3) to purpose a new plan under the Department of Public Works and Town \& Country Planning (DPT). This act can define the standards of transportation and land use management by the chapter $3,4,5$ and section of $17,18,19,27$, and 28 , respectively $[25,28]$. Therefore, the TAO can apply both policies to design and implement transportation and land use plans for SD of coastal tourism in Thailand.

Table 3. The Negative Environmental Impacts of Coastal Recreation Area in Thailand.

\begin{tabular}{|c|c|c|}
\hline No. & Key Issue & Indicator of Environmental Impact \\
\hline 1 & $\begin{array}{l}\text { Natural } \\
\text { Disasters }\end{array}$ & - $\quad$ Extreme weather conditions (e.g. impacts of monsoon and storm) \\
\hline 2 & $\begin{array}{l}\text { Coastal and } \\
\text { Marine } \\
\text { Ecosystems }\end{array}$ & $\begin{array}{l}\text { - } \\
\text { - } \\
\text { - } \\
\text { - }\end{array}$ \\
\hline 3 & $\begin{array}{l}\text { Pollution and } \\
\text { Environmental } \\
\text { Quality }\end{array}$ & $\begin{array}{l}\text { - } \\
\text { - }\end{array}$ \\
\hline 4 & $\begin{array}{l}\text { Infrastructure } \\
\text { and Facilities }\end{array}$ & $\begin{array}{l}\text { - } \\
\text { - Water scarcity (e.g. waterworks can't produce water supply and safe drinking water to serve the requirements of } \\
\text { people) } \\
\text { Access to recreational facilities and services (e.g. loss of access to recreation areas, restroom facilities and } \\
\text { accommodation for residents, older and persons with disabilities) }\end{array}$ \\
\hline 5 & $\begin{array}{l}\text { Transportation } \\
\text { and Land-use }\end{array}$ & $\begin{array}{l}\text { Transport accidents and parking capacities (e.g. poor linkage and condition of road system, and shortage of parking } \\
\text { space) } \\
\text { Mobility and traffic delay (e.g. loss of providing a perceived sense of greater reliability and predictability of } \\
\text { journey) } \\
\text { - } \quad \text { Land use change (e.g. property developers ignored the town and city planning act) }\end{array}$ \\
\hline
\end{tabular}

Source: Researcher 2013.

\section{Conclusions}

This article demonstrates the major environmental management policies and actions. It can be useful for solving environmental impacts and implementing the SD of coastal tourism in Thailand. The environmental impacts of coastal tourism are considered by literature reviews and in-depth interview, these impacts led over the years to the emergence of various approaches and planning methods, guided by essentially environmental management for SD. Also, environmental management policies are gathered by literature reviews for applying and providing the guidelines for the SD of coastal tourism in Thailand.

Therefore, this article propose the guidelines for the SD of coastal tourism that there are intended to solve issues related to the conflict between the need of tourism developmental and services requirements, as well as to preserve environment and resources in coastal tourism of country.

\section{Acknowledgements}

P. Nara would like to thanks the Department of Tropical Agriculture International Cooperation and the Graduate Institute of Landscape Architecture and Recreation Management, National Pingtung University of Science and Technology, Pingtung, Taiwan, and highly appreciates the departments of Thai government involved this study for the information. 


\section{References}

[1] World Travel \& Tourism Council. Travel \& Tourism 2011. World Travel \& Tourism Council, London: United Kingdom, 2011.

[2] United Nations Environment Programme. Disaster Risk Management for Coastal Tourism Destinations Responding to Climate Change: A Practical Guide for Decision Makers. Sustainable Consumption and Production Branch, Paris: France, 2008

[3] Department of Tourism. Tourist arrivals in Thailand, 2013. Retrieved on March 2, 2013 from http://61.19.236.137/tourism/th/home/tourism.php.

[4] Tourism Authority of Thailand. Tourism investment in Thailand, 2013. Retrieved on March 2, 2013 from http://www.tourisminvest.tat.or.th/.

[5] Phongphanich N, Mao G G, Yen K T B. Impacts of tourism development in Ban Had Rin community at Koh Phangan island, Thailand: A sustainable tourism perspective. Advanced Materials Research, 2013, 616-618: 1227-1230.

[6] Kim S G, Kim Y J E. Overview of coastal and marine tourism in Korea. Journal of Tourism Studies, 1996, 7(2): 46-53.

[7] Hall C M. Trends in ocean and coastal tourism: the end of the last frontier?. Ocean \& Coastal Management, 2001, 44: 601-618.

[8] World Commission on Environment and Development. Report of the World Commission on Environment and Development: Our Common Future. Oxford University Press, Oxford, 1987.

[9] World Tourism Organization, Indicators of Sustainable Development for Tourism Destinations: A Guidebook. World Tourism Organization, Madrid: Spain, 2004.

[10] Tsaur S H, Wang C H. The evaluation of sustainable tourism development by analytic hierarchy process and fuzzy set theory: An empirical study on the Green Island in Taiwan. Asia Pacific Journal of Tourism Research, 2007, 12(2): 127-145.

[11] Wong P P. Coastal tourism development in Southeast Asia: relevance and lessons for coastal zone management. Ocean \& Coastal Management, 1998, 38: 89-109.

[12] United Nations Environment Programme. Sustainable Coastal Tourism: An Integrated Planning and Management Approach. Sustainable Consumption and Production Branch, Paris: France, 2009.

[13] United Nations. The United Nations Framework Convention on Climate Change. New York: USA, 1992.

[14] Intergovernmental Panel on Climate Change. Climate Change 2007: Synthesis Report. Valencia: Spain, 2007.

[15] Aon Corporation. 2011 Thailand Floods Event Recap Report Impact Forecasting. Chicago: USA, 2012.
[16] Mekong Wetlands Biodiversity and Sustainable Use Programme. Vulnerability Assessment of Climate Risks in the Lower Songkhram River Basin, Thailand. Vientiane: Lao PDR, 2005

[17] Thampanishvong K. Background paper prepared for the global assessment report on disaster risk reduction 2013: The case of Thailand. Thailand Development Research Institute. Geneva: Switzerland, 2013.

[18] Green R. Community perceptions of environmental and social change and tourism development on the island of Koh Samui, Thailand. Journal of Environmental Psychology, 2005, 25: 37-56

[19] Saenger P. Environmental impacts of coastal tourism: an overview and guide to relevant literature. In IM Dutton \& P Saenger (eds), Environmental management of tourism in coastal areas : proceedings training workshop held in Bogor and Bali, Indonesia, July 4-24, 1989, SEAMEO-BIOTROP, Bogor, Indonesia, 1990, 1: 18-45.

[20] Maruani T, Irit A C. Open space planning models: A review of approaches and methods. Landscape and Urban Planning, 2007, 81: 1-13.

[21] Pomeroy R S. Community-based and co-management institutions for sustainable coastal fisheries management in Southeast Asia. Ocean \& Coastal Management, 1995, 27(3): 143-162.

[22] Larsen R K, Calgaro E, Thomalla F. Governing resilience building in Thailand's tourism-dependent coastal communities: Conceptualising stakeholder agency in social-ecological systems. Global Environmental Change, 2011, 21: 481-491.

[23] Department of Disaster Prevention and Mitigation. Disaster Prevention and Mitigation Act 2007, 2013. Retrieved on March 2, 2013 from http://61.19.54.137/law/dpmlaw/main/index.php.

[24] Department of Disaster Prevention and Mitigation. Thailand Country Report. Research and International Cooperation Bureau, Ministry of Interior, Thailand, 2006.

[25] Ministry of Tourism and Sports of Thailand. Thailand National Tourism Development Plan 2012-2016, 2013. Retrieved on March 3, 2013 from http://www.tica.or.th/images/plan_tourism2555-2559/2555-2 559.pdf.

[26] Pollution Control Department. Thailand State of Pollution Report 2011. The Interest, Bangkok: Thailand, 2012.

[27] United Nations Environment Programme. Environmental Codes of Conduct for Tourism. United Nations Environment Programme, Paris: France, 1995.

[28] Department of Public Works and Town \& Country Planning. Town Plan Act B.E. 2518 (1975), 2013. Retrieved on March 2, 2013 from http://www.dpt.go.th/wan/lawdpt/data/01/town_plan.pdf. 